\title{
ЗАБЕЗПЕЧЕННЯ СПРАВЕДЛИВОЇ ВИНАГОРОДИ ПЕРСОНАЛУ НА РІВНІ ІНСТИТУЦІЙНОГО РЕГУЛЮВАННЯ ТА НR-МЕНЕДЖМЕНТУ
}

\author{
Шаульська Лариса Володимирівна \\ доктор економічних наук, професор \\ Донецький національний університет імені Василя Стуса (м. Вінниця, Україна) \\ ORCID 0000-0002-7919-6733 \\ I.shaulska@donnu.edu.ua
}

Гринкевич Роман Ігорович аспірант Донецький національний університет імені Василя Стуса (м. Вінниця, Україна) ORCID 0000-0003-3048-6809 romaxa10@ukr.net

Обгрунтовано, що забезпечення справедливої винагороди персоналу вимагає консолідації інституційної сфери механізму державного регулювання (профрспілкових організацій як юридично встановлених структур захисту прав працівників; органів державної влади, які через створення умов бізнес-середовища та регламентацію концептуальних засад управління персоналом мотивують роботодавців до відповідних кроків) та HR-менеджменту (роботодавців як суб'єктів господарювання). Деталізовано процес забезпечення справедливої винагороди персоналу за інституційним, функціональним, ресурсним забезпечення, управлінським інструментарієм та поточними управлінськими діями. Охарактеризовано механізм нової системи мотивації та оплати праці персоналу, що включає: диференціацію персоналу; проведення оцінювання посад працівників; вибір системи оплати праці, ії форм, видів; вибір системи додаткових пільг і нематеріальної мотивації; формування структури компенсаиійних пакетів.

Ключові слова: справедлива винагорода, управління персоналом, мотивація праці, HR менеджмент.

DOI: https://doi.org/10.32845/bsnau.2019.4.24

Постановка проблеми. Забезпечення справедливої винагороди за трудову діяльність $€$ найважливішою складовою концепції гідної праці, спрямованої на обгрунтування пріоритетних напрямів соціальної політики щодо вирішення проблем у соціально-трудовій сфрері, забезпечення ефективної зайнятості та соціальної згуртованості. Реалізація концепції гідної праці має забезпечуватися інструментами державної соціальної політики. Це знайшло відображення у Європейській соціальній хартії «Право на справедливу винагороду» (1996р.) [1], Міжнародному пакті про економічні, соціальні та культурні права (1966р.) [2], Загальній декларації прав людини (1948р.) [3] та інших міжнародних нормах, які стосуються прав людини та соціально-трудової сфери.

Варто відзначити, що аналіз доходів від праці в Україні засвідчив накопичення проблем у сфері забезпечення гідної праці, серед яких: низький рівень заробітної плати та надмірна її диференціація, незначна їі частка в структурі доходів та, навпаки, велика питома вага соціальної допомоги та інших одержаних поточних транссрертів; збереження значних сум невиплаченої заробітної плати; поширення бідності серед працюючих тощо. Тому побудова ефективного механізму забезпечення справедливої винагороди персоналу залишається актуальною проблемою української економіки.

Аналіз останніх досліджень та публікацій. Проблема забезпечення справедливої винагороди за трудову діяльність, мотивації персоналу, технології управління людськими ресурсами є одними з актуальних питань в умовах становлення знаннєвої економіки та формування нової системи HR-менеджменту. До відомих зарубіжних науковців, що досліджують наведені питання варто віднести таких, як: С. Ананд, Б. Гройсберг, Д. МакКлеланд, С. Паркер, М. Фінні, Д. Хлоуп. Серед вітчизняних дослідників хочемо виокремити В.

Антонюк, О. Грішнову, С. Гринкевич, О. Іляш, Г. Капліну, А. Колота, Л. Семів, С. Цимбалюк, Л. Шевчук та ін.

Разом $з$ тим, сьогодні виникає зростаюча потреба у дослідженнях нової якості управління персоналом, що враховують стрімкий розвиток технологій, швидку адаптацію персоналу до поточних інновацій, динамічний розвиток компаній в умовах невизначеності. Зважаючи на те, що більшість підприємницьких структур та організацій зберігають структуру і принципи роботи XX століття, значна увага вчених повинна бути зосереджена на пошуку та втіленні більш сучасних підходів мотивування персоналу, гідної оплати праці що має забезпечуватися як інструментами державної соціальної політики, так і HR менеджментом.

Метою статті $€$ наукове обгрунтування забезпечення справедливої винагороди за трудову діяльність на рівні інституційної сфрери механізму державного регулювання та HRменеджменту.

Виклад основного матеріалу. Справедливу винагороду за трудову діяльність можна розглядати з двох аспектів: 1) як певний рівень оплати праці окремих працівників, що забезпечує нормальне відтворення робочої сили та можливості розвитку людського потенціалу родини працівника, $\epsilon$ адекватним його трудовим зусиллям та здобутій кваліфікації; 2) як відповідну систему оплати праці, яка забезпечує дотримання соціально-трудових прав найманих працівників, $€$ справедливою та здійснюється з використанням сучасних досягнень організації заробітної плати на підприємствах і в установах [4]. Справедлива винагорода за трудову діяльність (гідна заробітна плата) охоплює такий їі рівень, що здатен забезпечити економічну свободу працюючій людині і його сім'ї; створює базові основи для систем соціального страхового захисту і соціального забезпечення; дає можливість людині ро- 
звиватися, відпочивати, користуватися досягненнями цивілізації, відповідає поняттю справедливого розподілу результатів праці; заробляється в умовах, що не принижують гідність людини; вирішує проблему матеріальної бази для розширеного відтворення населення країни, забезпечення економіки кваліфікованими трудовими ресурсами [5]. Це досить розгорнуте визначення справедливої винагороди за трудову діяльність робить акцент на необхідному рівні заробітної плати.

Забезпечення справедливої винагороди за трудову діяльність нерозривно пов'язані з диференційованими інтересами різних учасників. При цьому така диференціація простежується навіть у вузьких сегментах тих учасників, для яких здавалося б поле інтересів $є$ абсолютно однорідним (табл. 1). Так, між працівниками, які здебільшого здійснюють свою тру- дову діяльність на засадах найму, інтереси диференціюються навколо цінностей трудової діяльності, які часто десормовані за умов важкого соціально-економічного становища в регіонах країни. Для різних працівників у силу сформованих світоглядних установок шкала цінностей трудової діяльності дисеренціюється В нинішніх умовах чітко вираженою є тенденція домінування матеріальних інтересів економічно активного населення в Україні, хоча усе більшої вагомості набувають можливості розвитку, кар'єрного зростання, підвищення соціального статусу, доступу до інформації тощо. Деформовані цінності полягають у можливості одержання додаткових неофіційних платежів, отримувати відповідну заробітну плату за мінімальних зусиль, доступу до владних ресурсів тощо [6]

Базис інтересів учасників соціально-трудових відносин *

Таблиця 1

\begin{tabular}{|c|c|c|c|}
\hline \multirow{2}{*}{ Учасник } & \multicolumn{3}{|c|}{ Диференціація інтересів } \\
\hline & Працівник & Роботодавець & Держава \\
\hline Працівник & Цінності трудової діяльності & Вимір оплати праці & Створення сприятливих умов трудової діяльності \\
\hline Роботодавець & Вимір продуктивності праці & Добросовісна конкуренція & Створення сприятливих умов бізнесової діяльності \\
\hline Держава & Вимір інноваційної активності & Фінансові результати діяльності & Національні інтереси \\
\hline
\end{tabular}

Забезпечення справедливої винагороди персоналу може бути досить складним завданням, адже вирішення проблеми відповідності рівня оплати праці працівника й інших форм стимулювання з такими параметрами, як освітньо-кваліфікаційний рівень, його повноваження та ступінь відповідальності, схильність до розвитку тощо вимагає консолідації інституційної сфери механізму державного регулювання (профспілкових організацій як юридично встановлених структур захисту прав працівників та органів державної влади, які через створення умов бізнес-середовища та регламентацію концептуальних засад управління персоналом мотивують роботодавців до відповідних кроків) та HR-менеджменту (роботодавців як суб'єктів господарювання).

У табл. 2 узагальнено відображено розподіл сфер відповідальності різних типів суб'єктів, які можуть брати участь у забезпеченні справедливої винагороди за працю, зокрема звернено увагу на функціональний розподіл між ними.

Таблиця 2

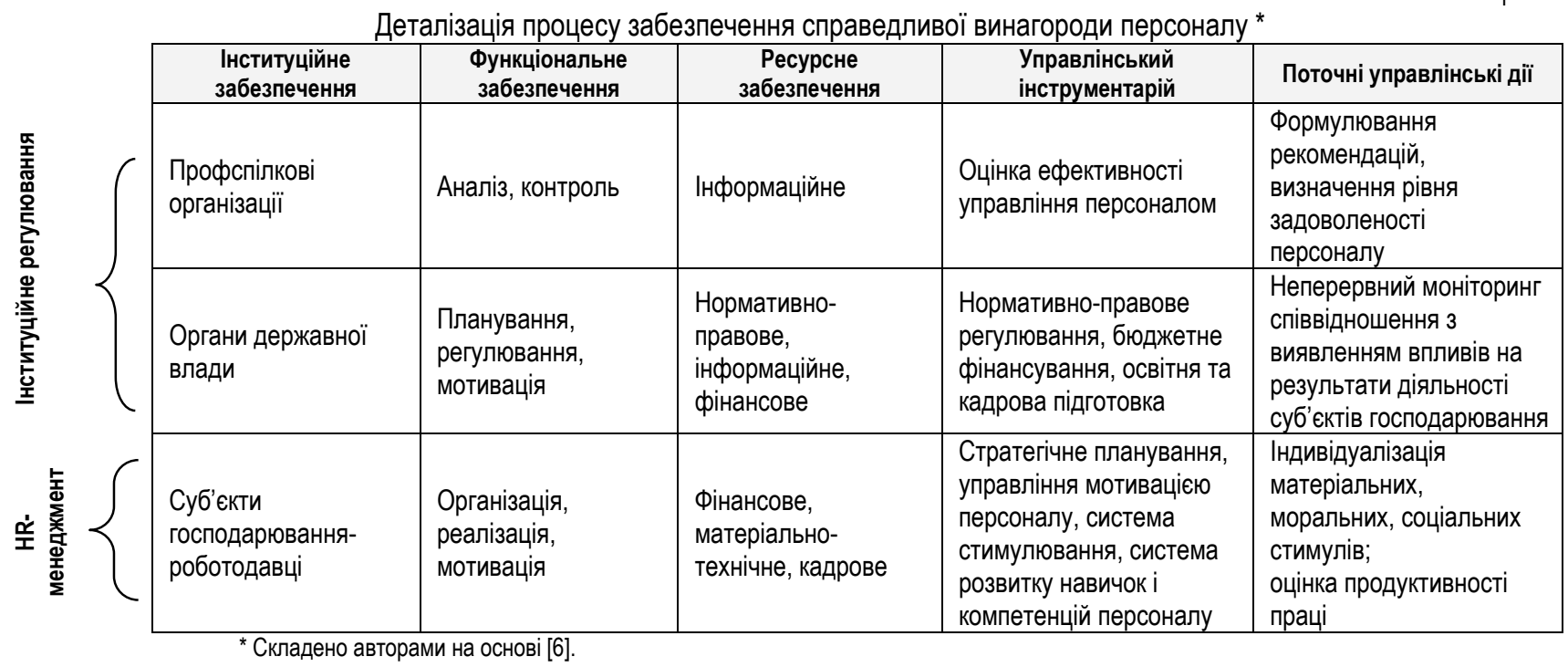

3 боку держави концептуальні зобов'язання за даним напрямом повинні відводитись Міністерству соціальної політики України, у тому числі в його структурі - Державній службі України з питань праці та Державній службі зайнятості України, Міністерству освіти і науки України, а також їх територіальним представництвам. Особливу роль тут відводимо Державній службі зайнятості України та її територіальним підрозділам, до напрямів діяльності якої належить величезний спектр співпраці з роботодавцями, у тому числі щодо роз'яс- нень норм законодавства та впровадження нових прогресивних форм управління персоналом. Потужною державною структурою тут також виступає Державна податкова служба України, адже через її управлінський інструментарій у значній мірі залежить формування сприятливого бізнес-середовища, що дозволить роботодавцю мобілізувати додаткові фінансові ресурси, спрямувавши їх на забезпечення справедливої винагороди за працю.

На макрорівні забезпечення справедливої винагороди персоналу повинно здійснюватися більш концептуально 
та в першу чергу (управлінський інструментарій тут може бути значно ширшим) через нормативно-правове регулювання, бюджетне фінансування (дотування), а також освітню та кадрову підготовку.

Щодо освітньої та кадрової підготовки, то тут маємо на увазі передусім формування державного замовлення на підготовку фахівців і робітничих кадрів у розрізі різних освітньо-кваліфікаційних характеристик. Важливо, щоб чітко дотримувався підхід врахування ринкових умов з потребою у працівниках відповідної кваліфікації, а також стратегічні пріоритети розвитку держави та її регіонів, виходячи з ресурсного потенціалу. На обсяги державного замовлення на підготовку фахівців та робітничих кадрів в умовах становлення знаннєвого суспільства можуть також активно впливати бурхливий розвиток IT-технологій, що вимагає фахівців нового профрілю і для підготовки яких слід розробляти нові прогресивні освітні програми та здійснювати відповідне матеріально-технічне забезпечення. Також хочемо зазначити, що освітні установи можуть виступати потужними генераторами ідей щодо можливих управлінських рішень у рамках забезпечення справедливої винагороди персоналу з якісним теоретико-методологічним обґрунтуванням можливих напрямів такого забезпечення та із базуванням на кращому зарубіжному досвіді, а також акумульованих століттями знаннях у сформованих теоріях і концепціях.

Функції проффспілкових організацій мають в основному зводитись до аналізу і контролю діяльності роботодавця щодо дотримання вимог відповідності рівня оплати праці та стимулювання 3 іншими означеними характеристиками трудової діяльності. Аналітичні матеріали профспілкових організацій повинні стосуватись не лише діяльності суб'єктів господарювання за цим напрямом, але й держави, зокрема:

- щодо ефективності її концептуальних підходів у забезпеченні справедливої винагороди персоналу;

- щодо ефективності реалізації регламентованих державою концептів на конкретному підприємстві з простеженням можливих причин такого стану справ (цінними тут будуть дослідження в розрізі підприємств за різними видами економічної діяльності);

- щодо сприйняття відповідних нововведень, які зокрема можуть відбуватись і в рамках соціальних інновацій, самими працівниками-носіями трудового потенціалу.

Управлінський інструментарій профспілкових організацій при цьому повинен враховувати оцінювання ефективності управління персоналом через визначення ступеня задоволеності працівників своєю роботою. Звичайно, це дуже важливий індикатор конкурентоспроможності персоналу в якісному аспекті, адже задоволений умовами праці працівник здійснює свою трудову діяльністю з вищою продуктивністю та $€$ більш схильним до інноваційності (звичайно, це за умов здійснення трудової діяльності на законних засадах без проявів задоволеності працею через можливості одержання доходів незаконним шляхом та інших асоціальних проявів). У випадку вживання заходів роботодавця щодо балансування рівня оплати праці з кваліфікацією, професіоналізмом та іншими означеними характеристиками, профспілкові організації як структури, до яких у працівника проявляється вищий ступінь довіри, повинні виявляти можливі зміни в його поглядах, виникнення нових мотивів, у тому числі щодо розвитку, внаслідок активної мотиваційної політики підприємства.

При деталізації процесу забезпечення справедливої винагороди персоналу важливо досить ретельно продумати можливий управлінський інструментарій до застосування, який помітно диференціюється між різними суб'єктами.

В сучасних організаціях розробка систем оплати працівників, а відповідно і забезпечення справедливої винагороди персоналу покладено в функціональні обов'язки фахівців з HR-менеджменту. Варто зазначити, що система HR-менеджменту базується на вмінні ефективно поєднувати цілі всієї команди із індивідуальним підходом до кожного учасника. Технології HR-менеджменту пов'язані зі зміною бачення щодо людського ресурсу. В підсумку HR-менеджмент демонструє ефективний результат роботи і утримує баланс між підходами до управління персоналу.

Для досягнення економічного результату господарської діяльності і одночасної реалізації потреб персоналу на підприємствах застосовують різноманітні методи управління персоналом.

Одним $з$ найпопулярніших вважається метод управління персоналом за допомогою мотивації. Мотивація - це бажання людини виконувати певну роботу, зумовлене тим, що це задовольняє ту чи іншу її потребу [7]. Одна з головних проблем мотивації - велике різноманіття життєвих орієнтирів співробітників - те, що є привабливим для одних, не зацікавить інших. Очевидно, що топ-менеджер та некваліфікований працівник потребують різної мотивації, і це справедливо не лише для працівників різного рівня. Справжня проблема побудови мотиваційної стратегії полягає в тому, що навіть персонал одного рівня має різні потреби і це необхідно враховувати.

Управління персоналу залежить від глобального вивчення потреб, інтересів, особистих цілей і прагнень співробітників. При розробці цілей і завдань системи мотивації та оплати праці повинні враховуватися наступні чинники: цілі та завдання підприємства (організації), його стратегічне позиціонування на ринку праці, організаційна культура, ціннісні характеристики, характеристики робочого колективу. Тут варто зрозуміти можливість інтеграції мотивації співробітників, з виробничими вимогами роботодавців. Важливу роль також відіграє кадрова політика, зорієнтована на розвиток навичок і компетенцій персоналу, підтримання сприятливої моральнопсихологічної атмосфрери в колективі.

Відтак, цілі і завдання нової системи мотивації повинні корелюватися зі стратегією і цілями організації.

Зазначимо, що в сучасних умовах основними кроками при розробці та впровадженні нової системи мотивації та оплати праці на підприємствах мають виступати: диференціація персоналу; проведення оцінювання посад працівників; вибір системи оплати праці, її форм, видів; вибір системи додаткових пільг і нематеріальної мотивації; формування структури компенсаційних пакетів.

Диференціація персоналу слугує основою для побудови грейдингу, системи преміювання та пільг, а також компенсаційних пакетів. Система грейдування $є$ різновидом матеріальної мотивації персоналу. В її основі лежить оцінка цінності посади працівника для організації чи підприємства і створення ієрархії посад з відповідними окладами. Застосування грейдів $€$ одним 3 інструментів регулювання оплати праці, внутрішнім проектом підприємства, основою для втілення управлінських механізмів мотивації і розвитку персоналу. Грейдування дозволяє ефективно управляти кадровим потенціалом компанії: об'єктивно і справедливо оцінювати 
працю усіх спеціалістів і втримувати кращих. Порівняно зі стандартними тарифікаційними процедурами, грейдування $€$ більш досконалою формою заробітної плати, оскільки дозволяє у повній мірі врахувати індивідуальні потреби підприємства в диверсифікації заробітної плати [8].

Далі проводиться внутрішня оцінка посад працівників підприємства, яка передбачає в підсумку формування структури посад за категоріями та грейдами (розрядами, рангами тощо). Варто зазначити, що в сучасному кадровому менеджменті найчастіше використовуються кількісні (факторний, бально-фракторний) і некількісні (простого ранжування, парного порівняння, класифікації) методи оцінювання посад.

Так, за допомогою факторного методу можна проранжувати види робіт за складовими, що їх формують (знання, навики, повноваження, відповідальність, управління), порівняти їх вагомість і присвоїти числове значення на основі аналізу внутрішніх і зовнішніх даних. Бально-факторний метод дає можливість оцінити посади за такими характеристиками як знання, вирішення проблем, відповідальність. Метод простого ранжування передбачає розподіл посад організації за рангами шляхом експертної оцінки. Парне порівняння засноване на виокремлені груп посад на підприємстві і порівнянні їх між собою за певними критеріям. Метод класифрікації передбачає порівняння кожної посади з описаними загальноприйнятими стандартами. Зауважимо, що вибір методу оцінки посад залежить від стадії життєвого циклу компанії, її розміру, рівня розвитку системи управління персоналом, рівня забезпечення фінансовими, кадровими, технологічними ресурсами. Так, невеликі підприємства, в основному, використовують некількісні методи, достатньо розвинуті - метод класифікації, а великі - схиляються до застосування складних кількісних методів оцінювання посад.

При виборі системи і форм оплати праці широко використовують такі форми оплати праці, як відрядна, погодинна, тарифна і безтарифна. На зарубіжних підприємствах спостерігається розширення погодинної системи на основі фіксованого окладу за методом грейдування і змінної частини оплати, що включає усілякі премії, бонуси, комісійні та премії. Досить поширеною практикою є включення в систему мотивації і оплати праці додаткових пільг і нематеріальної мотивації, що в результаті дає можливість сформувати компенсаційний пакет для кожної з посад.

3 точки зору мотивації основна мета введення додаткових пільг - це прояв турботи про співробітників зі сторони компанії для забезпечення їх лояльності. Додаткові пільги (понад пільг, які встановлюються державою трудовим законодавством) розглядаються як винагороди, не пов'язані з кількістю і якістю праці. Співробітники найчастіше отримують їх за факт трудової діяльності на даному підприємстві (в організації).

Варто зазначити, що додаткові пільги часто перетинаються (об'єднуються) 3 нематеріальною мотивацією, яка може мати інші цілі мотивації працівників - створення у них почуття причетності до успіхів компанії, визнання заслуг співробітників, їх залучення в життя компанії, заохочення за високі результати. Нематеріальна мотивація включає як матеріальне, так і моральне заохочення.

Термін «компенсаційний пакет» відрізняється від традиційного розуміння компенсацій, передбачених трудовим законодавством. На думку А. М. Колота та С. О. Цимбалюк, компенсаційний пакет є сукупністю всіх (матеріальних і нематеріальних) виплат, винагород, благ і послуг, що їх роботодавець надає працівникові за використання його робочої сили (компетенцій) відповідно до норм чинного законодавства, положень корпоративної політики, умов колективного та трудового договорів [9]. Розробка різних компенсаційних пакетів $€$ одним 3 найважливіших стратегічних завдань управління людськими ресурсами. Склад компенсаційного пакета повинен задовольняти потреби співробітників і бути збалансованим за видами винагород і пільг. Перш ніж включати в компенсаційний пакет той чи інший вид винагороди, необхідно ретельно проаналізувати характеристики колективу і мотиваційні профілі співробітників.

Як зазначає науковець Сарай Н. І., важливе місце в структурі компенсаційного пакета має соціальний пакет. Частина виплат і заохочень, які формують соціальний пакет, належить до фонду заробітної плати: матеріальна допомога, що має систематичний характер, надана всім або більшості працівників (на оздоровлення, у зв'язку з екологічним станом), оплата або дотації на харчування, оплата за утримання дітей працівників у дошкільних закладах, путівок на лікування, відпочинок та екскурсії, проїзних квитків, абонементів у групи здоров'я, передплати на газети та журнали тощо [10].

Варто зазначити, що структура і розмір пакета на підприємствах суттєво різняться залежно від фінансових можливостей, специффіки посади, кон'юнктури ринку праці, трудового законодавства тощо. У великих компаніях тенденція формування компенсаційних пакетів полягає у збільшенні частки додаткових пільг і нематеріальних винагород в загальній системі винагород. Розвинена соціальна політика присутня в тих компаніях, де цінується людський капітал. І, як засвідчує досвід, вони виявляються найбільш ефективними і успішними у своєму бізнесі.

Звичайно, можливих методів, інструментів та важелів управління персоналом може бути значно більше. Якщо концентруватись на методах, то їх традиційно слід розрізняти в розрізі адміністративно-правових, фінансово-економічних та соціально-психологічних. За нинішніх умов становлення знаннєвого суспільства та необхідності ефективного розвитку і використання персоналу підприємства особливої ваги набуває саме група соціально-психологічних методів, передбачаючи широкий інструментарії ідеологічного, просвітницьковиховного, інформаційного характеру. Власне саме у межах соціально-психологічних методів повинен реалізовуватись комплексний, системний, цілеспрямований механізм формування в персоналу підприємства здорових мотивів до трудової діяльності з можливостями одержання такого рівня доходу та інших соціальних благ (у тому числі в межах соціального пакету), які відповідають рівню кваліфікації, професіоналізму, відповідальності за даною посадою. Разом з тим, важливими залишаються адміністративні методи управління персоналом, зокрема стратегічне планування. Це означає, що повинно бути чітко визначено згідно загальних стратегічних пріоритетів розвитку даного підприємства, яка структура персоналу за освітньо-кваліфікаційними характеристиками повинна бути на визначений період, адже від цього в значній мірі залежить успішність його діяльності в цілому (людський чинник як визначальний для розвитку бізнесу.

Висновки. Отже, забезпечення справедливої винагороди за трудову діяльність $є$ комплексним завданням, яке 
має виконуватись з консолідацією зусиль на різних управлінських рівнях: інституційному - через органи державної влади та профспілкові організації; рівні підприємств - застосовуючи інструменти HR-менеджменту. У випадку невідповідності рівня оплати праці, інших форм стимулювання та рівня кваліфікації працівника, його повноважень, ступеня відповідально- сті, схильності до постійного підвищення рівня професіоналізму тощо і надалі буде поглиблюватись явище демотивації продуктивної трудової діяльності зі схильністю до інноваційності, прагнення постійного розвитку і виконання посадових зобов'язань не з мінімальними зусиллями, а з повною віддачею. I за таких умов говорити про есрективність розвитку і використання персоналу є неможливо.

\section{Список використаної літератури:}

1. Європейська соціальна хартія. URL: http://zakon3.rada.gov.ua/laws/show/994_062.

2. Міжнародний пакт про економічні, соціальні та культурні права. Міжнародний документ від 16.12.1973. URL: http://zakon0.rada.gov.ua/laws/show/995_042

3. Загальна декларація прав людини. Прийнята і проголошена резолюцією 217 А (III) Генеральної Асамблеї ООН від 10 грудня 1948 року. URL: http://zakon3.rada.gov.ua/laws/show/995_015/print1475484759796824.

4. Антонюк В.П. Соціальна політика у сфері оплати праці: проблеми та шляхи забезпечення іï гідного рівня (на прикладі промисловості). Управління економікою: теорія та практика: Зб. наук. пр. К.: IЕП НАНУ, 2016. С. 3-24.

5. Капліна Г. А. Характеристика концепції гідної праці в Україні. Актуальні проблеми права: теорія і практика: зб. наук. праць. Луганськ: Східноукраїнський нац. ун-т ім. В. Даля, 2013. № 26. С. 47-54.

6. Гринкевич С. С. Трансформації відтворення трудового потенціалу України в інформаційній економіці. Львів: Львівська комерційна академія, 2013. 349 с.

7. Трапицына С. Ю. Мотивация персонала в современной организации: Учебное пособие. СПб.: ООО «Книжный Дом», 2007.

8. Ситник Н. І., Жиганівський А. А. Грейдування посад у системі мотивації персоналу. Матеріали VI Всеукраїнської науково-практичної конфреренції «Сучасні підходи до управління підприємством». 2015. С. 503-508.

9. Колот А. М., Цимбалюк С. О. Мотивація персоналу: підручник. К.: КНЕУ, 2011. 397 с.

10. Сарай Н. І. Компенсаційний пакет підприємства: сутність та структура. Сталий розвиток економіки. 2013. № 4. С. 110-114.

\section{References:}

1. The Verkhovna Rada of Ukraine (2014). Yevropeys'ka sotsial'na khartiya [European Social Charter]. URL: http://zakon3.rada.gov.ua/ laws/show/994_062

2. The Verkhovna Rada of Ukraine (1973). Mizhnarodnyy pakt pro ekonomichni, sotsial'ni ta kul'turni prava [International Covenant on Economic, Social and Cultural Rights]. URL: http://zakon0.rada.gov.ua/laws/show/995_042

3. The Verkhovna Rada of Ukraine (1948). Zahal'na deklaratsiya prav lyudyny. Pryynyata i proholoshena rezolyutsiyeyu 217 A (III) Heneral'noyi Asambleyi OON [Universal Declaration of Human Rights. Adopted and promulgated by UN General Assembly Resolution 217 A (III)] vid 10 hrudnya 1948 roku. URL: http://zakon3.rada.gov.ua/laws/show/995_015/print1475484759796824.

4. Antonyuk, V.P. (2016). Sotsial'na polityka u sferi oplaty pratsi: problemy ta shlyakhy zabezpechennya yiyi hidnoho rivnya (na prykladi promyslovosti) [Social policy in the field of wages: problems and ways to ensure its decent level (on the example of industry)]. Upravlinnya ekonomikoyu: teoriya ta praktyka - Economic management: theory and practice, 3-24.

5. Kaplina, H. A. (2013). Kharakterystyka kontseptsiyi hidnoyi pratsi v Ukrayini [Characteristics of the concept of decent work in Ukraine]. Aktual'ni problemy prava: teoriya i praktyka - Actual problems of law: theory and practice, 26, 47-54.

6. Hrynkevych, S. S. (2013). Transformatsiyi vidtvorennya trudovoho potentsialu Ukrayiny v informatsiyniy ekonomitsi [Transformations of reproduction of labor potential of Ukraine in information economy]. L'viv: L'vivs'ka komertsiyna akademiya.

7. Trapytsyna, S. Yu. (2007). Motyvatsyya personala v sovremennoy orhanyzatsyy [Motivation of staff in a modern organization]: SPb.: LLC "Book House".

8. Sytnyk, N. I., Zhyhanivs'kyy, A. A. (2015). Hreyduvannya posad u systemi motyvatsiyi personal [Grading positions in the system of staff motivation]. Materialy VI Vseukrayins'koyi naukovo-praktychnoyi konferentsiyi «Suchasni pidkhody do upravlinnya pidpryyemstvom», 503-508.

9. Kolot, A. M., Tsymbalyuk, S. O. (2011). Motyvatsiya personalu [Motivation of staff: a textbook]. K.: KNEU, 2011. 397 s.

10. Saray, N. I. (2013). Kompensatsiynyy paket pidpryyemstva: sutnist' ta struktura [Compensation package of the enterprise: essence and structure]. Stalyy rozvytok ekonomiky - Sustainable economic development, 4, 110-114.

Shaulska Larysa Volodymyrivna, Dr of Economics, Professor, Vasyl Stus Donetsk National University (Vinnytsia, Ukraine) Hrynkevych Roman Ihorovych, PhD student, Vasyl Stus Donetsk National University (Vinnytsia, Ukraine)

\section{Ensuring fair remuneration of staff at the level of institutional regulation and HR-management}

Ensuring fair remuneration for work is the most important component of the concept of decent work, aimed at justifying the priority areas of social policy to address problems in the social and labor sphere, ensuring effective employment and social cohesion. The implementation of the decent work concept should be ensured by the instruments of state social policy. This is reflected in the European Social Charter "The Right to Fair Remuneration", The International Covenant on Economic, Social and Cultural Rights, The Universal Declaration of Human Rights and other international norms relating to human rights and social and labor sphere. Fair remuneration for work can be considered from two aspects: 1) as a certain level of remuneration of individual employees, which 
ensures the normal reproduction of labor and opportunities for human development of the employee's family, is adequate to his work effort and qualifications; 2) as an appropriate system of remuneration, which ensures compliance with the social and labor rights of employees, is fair and carried out using modern advances in the organization of wages in enterprises and institutions. It is substantiated that ensuring fair remuneration of staff requires consolidation of the institutional sphere of the state regulation mechanism (trade unions as legally established structures for protection of workers' rights; public authorities that motivate employers to take appropriate steps by creating business environment and regulating conceptual principles of personnel management) and HR -management (employers as business entities). The process of ensuring fair remuneration of staff for institutional, functional, resource support, management tools and current management actions is detailed. The mechanism of the new system of motivation and remuneration of personnel is characterized, which includes: differentiation of personnel; evaluation of employee positions; choice of remuneration system and its forms, types; choice of a system of additional benefits and intangible motivation; formation of the structure of compensation packages.

Key words: fair remuneration, personnel management, work motivation, HR-management.

Дата надходження до редакції: 20.10.2019 р. 